\title{
Effective Pedagogy For Business Schools Post-9/11/01
}

\author{
Susan P. Eisner, (E-mail: seisner@ramapo.edu), Ramapo College of New Jersey
}

\begin{abstract}
In the year since the 9/11/01 terrorist attacks on the United States, many educators have sought ways to respond appropriately and effectively in their classes. Much has been written to guide elementary and secondary educators; it is largely curricular in nature. Little has yet been geared toward college educators or pedagogy. This paper begins to serve that need by presenting pedagogical options business school instructors may find helpful. The literature review and results of a student survey suggest that active learning may be particularly effective in business school teaching today.
\end{abstract}

\section{Introduction}

ow did a terrorist attack successfully access the Pentagon? How did our airports allow this to
happen? How do we react to people who are glad this happened? How will life change socially and
economically if the US goes to war? Where will relief money come from? Did the U.S. shoot down the plane in Pennsylvania? Is this the end of the world?

These questions are representative of those asked in the first days after the terrorist attacks of 9/11/01. What makes them particularly notable is who asked them publicly - not the media, not public figures, but freshman business school students at Ramapo College of New Jersey, located 45 minutes from Ground Zero.

In the year since, many colleges have sought ways to serve the "teachable moment" they saw. A variety of curricular initiatives ranging from one-credit courses to panels of experts to re-oriented seminars have been created. Educators seeking guidance as they fast track responsive curriculum can learn from the general media what others are trying. But is still too soon for much of the academic literature to have published relevant reviewed articles.

This paper is designed to begin to provide such a resource to business school faculty exploring teaching options one year into the war on terrorism, with its ripple effect on students and heightened need for cooperation between business, government, and society. It presents a snapshot of current U.S. public opinion, the psychological impacts of terrorism, concurrent relevant issues, and media habits of "Gen Y" to better understand our students' frames of reference. These suggest that active learning pedagogy - with its student-driven foundation - may be particularly effective in teaching today.

Specific pedagogical recommendations and examples of active learning vehicles used at the School of Administration and Business of Ramapo College post-9/11 are included. It is from these that the above questions were generated, and through which a "teachable moment" became a stimulating year characterized by deep learning.

\section{Frames of Reference}

Communication, psychology, active learning, and multiple intelligence literature suggest that effective learning is facilitated when student frame of reference is taken into account and compatible with pedagogy -

Readers with comments or questions are encouraged to contact the author via email. 
knowing "where our students are coming from" can help us reach them in the classroom. One year into the war on terrorism, U.S. college students live in a country where most agree terrorists able to launch a major attack against the US are living in the U.S., the "state of the country" satisfaction rating is $47 \%, 54 \%$ feel U.S. economic conditions are getting worse, and 76\% rate economic confidence as only fair/poor (Gallup Poll 9/17/02, 9/10/02). The 9/11 terrorist attack and corporate greed/corruption are blamed for the economic downturn (Moore, 2002), which brought the number of jobs lost during 2001 to 1.1 million. That was the largest annual job drop in two decades, and is predicted by some to result in an additional 1.6 million lost jobs in 2002 (Economy - Overview, 2002). In July, Time predicted a third straight year of market losses for the first time since WW II (Gibbs, 2002).

Since 9/11/01, a majority of Americans have been concerned about another terrorist attack. Trust in government and media both increased after 9/11/01, but have now fallen (One Year Later, 2002); public positive opinion of media performance has dropped $24 \%$ to only $49 \%$ since November 2001, and is now lower than it was before 9/11/01 (Impact on the News, 2002). Most Americans keep up with national and local news most of the time, but track international news only when major development occur; lack of background information to keep up appears to be a factor in relatively low interest in international news (Public's News Habits, 2002). College students surveyed as the U.S. entered Afghanistan in 2001 found 70\% supporting ground troops being sent, 70\% opposing the draft, and 70\% having donated blood or money or having volunteered in relief efforts after 9/11/01 (Berke, 2001). That general desire to "do good" coincided with a sluggish economy leaving many college seniors without solid job offers at graduation and may have translated into greater interest in public service careers. Since 9/11/01, Peace Corps applications have increased 20\%; Columbia Teachers College application rose 13\% (Murdock, 2002).

The impact of online news is substantial among those under 30 years old. They get more of their news online, where they can get it at their own schedule, than from any format excepts local TV news; $65 \%$ of those who go online come across news when they go online for another reason (Public's News Habits, 2002). Young people tend to read books but not newspapers, they read news magazines and watch morning TV shows, and $63 \%$ report wanting more time to devote to news (Kohut, 2002). Home for the summer, teens and college students boost ratings of talk shows with themes they find of interest (Pursell, 2002).

Common emotional responses when impacted by war or its threat include fear, loss of control, anger, loss of stability, isolation, and confusion (Goode/Eakin, 2002). New York State estimated that 3.1 million people in and around New York City would experience substantial emotional distress post-9/11/01, and that at least 500,000 would develop post traumatic shock distress (Goode/Eakin, 2002). A survey of Arizona college students and staff soon after 9/11/01 found a high level of distress, though they lived far from the attack sites. Valuing family and friends more, becoming involved in community, and expressing positive forms of patriotism were among coping strategies they chose (Clay, 2002).

Psychologists say that those closest to the attack sites, females, and those with insufficient coping strategies are most likely to experience post-traumatic stress symptoms. Additionally, indirect exposure to mass violence can lead to increased human connectedness, volunteerism, charity, and tolerance (Daw, 2002). Ability to make meaning from events - having witnesses to one's life, being able to tell one's stories to sympathetic listeners - can make a person a crisis survivor rather than a victim (Serlin, 2002).

\section{Generation Y (Those Born 1977-1994)}

Today's college freshman are of the 71 million "Gen Y." They do not remember the Cold War and have never feared nuclear war. Their formative generational events, instead, include the Columbine High School shootings - which brought school safety and gun violence home and left them fearful within their communities; MTV - which is by far the favorite cable channel of college students and with video games has attuned them to a visual style of loud graphics and rapid movements; celebrity scandals - which has left them much more judgmental about ethical behavior than the public at large and most admiring of those that they know; diversity - which accustoms them to a variety of global viewpoints and nontraditional families; the 2000 presidential election - which left them feeling a strong need for political reform and that their vote matters; and talk show/reality TV - which has given them a populist sense that every voice gets equal hearing and everyone can be a star (Paul, 2001). 
As a result, Gen $Y$ tends to be mistrustful of the media, which they think both misrepresents their views and exploited the Columbine shootings and scandals. They appear to be less responsive to traditional lecture methods, and do not unquestioningly look up to public figures. Celebrities are not Gen Y heroes - the majority of college seniors cite a parent as the person they most respect. Gen Y'ers are less likely to believe that there is any one right answer. Getting heard, having their say, and becoming known seem to them both easy and natural. (Paul, 2001).

The spread of talk shows on TV, radio, and Internet continues. Chat is the fastest-growing Internet activity, and Internet audiences tend to have more education and income (a demographic compatible with the collegeeducated) than radio and TV audiences. Magazine editor Michael Harrison explains why talk shows attract so many: "People don't know their neighbors anymore, and they wouldn't have time to talk over the backyard fence even if they did. But there's still a human need for community, so it's a virtual, electronic, global media community." Reallife topics appear to be most interesting to young listeners, with women drawn more to personal and private themes and men drawn more to political and public topics (Heath, 1998).

Market-researcher Michael Woods says the talk show mentality has affected how Gen Y learns: "What's changed the whole classroom atmosphere are shows like Jerry Springer. They think it's okay to be disruptive and to challenge what's being said. There's the 'prove it to me' mentality. And teachers and everyone in the school environment are struggling right now with figuring out how to teach that mentality" (Paul, 2002).

\section{Responses for Teachers When Students Are Coping with Trauma/Terrorism}

An article in Link-up articulates the broad range of those impacted by 9/11/01 that has been described by many: "Many people were affected directly by the attacks, and others became secondary victims as they consumed continuous news reports. All Americans now live under the threat of terrorism ... An important fact to remember is that you are not alone in your feelings" (Stevens, 2002).

Studies show that "violence inflicted by human beings exacts a greater psychic toll than the impersonal cruelty of nature ... (terrorist acts are) a means to the end of spreading fear and panic, the first step toward a fragmenting of society" (Goode/Eaken, 2002). Experts providing guidance for teachers whose students are coping with trauma/terrorism stress the important role to be played by teachers. The National Association of School Psychologists stresses the need for teachers in particular to help students understand current events factually, to explain how those events do or do not impact their lives, and how to handle their emotional reactions (Children and Fear of War and Terrorism, 2002). They tell us that older students are likely to have strong and varying opinions about the causes of and threats posed by current events, to share concrete suggestions, and to want to do something to help (A National Tragedy, 2002).

Specifically, the National Association of School Psychologists says it is important that teachers provide opportunity for students to discuss their concerns, maintain structure and stability, provide information directly to students, be aware of whose who have recently experienced personal tragedy, be careful not to stereotype people or countries that might be associated with the tragedy, provide an outlet for student desire to help, and monitor viewing of the event and its aftermath (A National Tragedy, 2002).

\section{Effective College Teaching Methods After 9/11/01: Student Survey/Findings}

A two-institution survey was conducted in September 2002 to determine student experience with and opinions of various teaching methods in the year since 9/11/01. Ramapo College is a four-year public college in the New Jersey state system, and is located about 45 minutes northwest of New York City. Nassau Community College is a two-year public college in the New York state system, and is located about 45 minutes east of New York City. The questionnaire asked the extent to which the events of 9/11/01 and the war on terrorism have been discussed in classes, the extent to which students wanted such discussion, the level of student interest in current events and terrorism before and after $9 / 11 / 01$, the extent to which various teaching methods were used and effective post9/11/01 in discussing the events, and the extent to which students wanted those teaching methods to be used. 
The sample was selected to reflect various factors relevant to this study. Both lower and upper level courses, attended by both business and liberal arts students, were surveyed. Fifty-two percent of the 118 respondents were business majors. Forty-eight percent of respondents were undecided or liberal arts majors. Most respondents attend Ramapo College, where business school classes were surveyed. One-quarter of respondents attend Nassau Community College, where psychology classes were surveyed. An equal number of male and female students responded. Thirty percent of respondents were on active duty or knew someone who was, when responding. Thirty percent of respondents were at the World Trade Center or knew someone who was on 9/11/01.

The survey included twelve teaching methods known to be used in college classes, and consistent with those the literature reviewed above would suggest to be constructive: teacher lectures to class, teacher answers student questions, teacher leads class discussion, student groups discuss the events with teacher support, student groups conduct research about the events and report to class, students tell their experiences with the events to class, students share their opinions/feelings about the events with class, guest speakers talk with class, class discusses the events as seen in media/film/Internet, teacher recommends media/film/Internet for interested students to learn more about the events outside of class, graded assignments incorporate the events, and optional/extra credit assignments incorporating the events. Survey results are detailed in Appendix A. Key findings include:

- $\quad$ Discussion was high, and highest, on and within the month after 9/11/01; it has been relatively low since.

- Respondents highly wanted discussion on or within the first month after 9/11/01; their preference is lower, and at a moderate level, now.

- $\quad$ Most respondents reported a high level of interest in both current events and terrorism beginning with and continuing since $9 / 11 / 01$.

- The most highly used teaching methods were teacher-student, in-class centered: teacher answering student questions, students sharing opinions/feelings with class, teacher leading class discussion, teacher lecturing to class, and students telling their experiences to class. Of these, interactive methods were seen by respondents as more effective than lecture.

- $\quad$ Those five most highly used methods were among the methods preferred by respondents both at 9/11/01 and at 9/02, with teacher lecturing less preferred for 2002 than at 9/11/01.

- $\quad$ Respondents would have preferred more usage of those teaching methods both at 9/11/01 and at 9/02.

- Respondents are interested in more usage of some active/experiential learning methods including discussion of the events as seen in media/film/Internet, student groups discussing the events with teacher support, and guest speakers talking about the events with the class.

- Opportunity to have questions answered, to share opinions/feelings/experiences, and to engage in teacherfacilitated peer discussion were the methods most preferred by respondents both at 9/11/01 and at 9/02

- $\quad$ 4-year college respondents, surveyed in business classes, reported greater preference for methods surveyed overall than did 2-year college respondents, surveyed in psychology classes. They also reported greater preference for each individual method except for teacher lectures to class, and graded assignments.

- 4-year college respondents, surveyed in business classes, reported a relatively high level of interest in eight out of the twelve methods surveyed; 2-year college respondents were highly interested in four methods.

- $\quad 9 / 11 / 01$ raised interest at both 4-year and 2-year colleges in current events/terrorism, and is relatively high.

- 4-year college respondents, surveyed in business classes, reported more class discussion now re: the events, a consistently greater desire for that discussion, and a stronger interest in both current events and terrorism than did 2-year college respondents, surveyed in psychology classes. They also reported wanting more discussion of the events at all times surveyed for than occurred.

- 2-year college respondents reported more discussion of the events in AY 2001-2002 than did 4-year.

Respondent comments are also contained in Appendix A. They include the following:

- $\quad$ "I believe the events of $9 / 11$ had such a grip on people that the topic was intentionally not discussed. Perhaps the type of classes had something to do with this perception. Unfortunately, one of my closest friends worked in WTC1."

- $\quad$ "I am a business student. Only one of my teachers discussed 9/11 and that was only done once a year later. 
I really wanted to discuss the results in class but was never given the opportunity."

- $\quad$ "I had a very delayed reaction to the events of 9/11, and when it did hit me, no one was really talking about it. So I wasn't really sure if I was the only one still thinking about it. I think teachers should reach out a little more to students especially after an event like that."

- $\quad$ "It was discussed at every graduation I went to ...; it's time to move on. I'm interested when we are under terrorist warning. Teachers' effectiveness is limited, as they are as baffled as students"

- $\quad$ "Lecturing doesn't do any good in the last. The most effective way to speak about terrorism etc. is to lead discussions with students being actively involved. Times have changed and so has society. If children aren't involved more in class, how are we teaching them to be intelligent leaders of tomorrow?"

- "What helped me get through the tragedy were relaxed class discussions that would go all period during the week after 9/11. Now media and lectures are more stimulating."

- $\quad 9 / 11 / 01$ is something of interest to everyone. Therefore, whatever is related in teaching to these horrible events will be more interesting. This could be a more effective teaching method."

\section{Synergy}

As a management professor at Ramapo College, I teach some 120 students each semester in business school classes at both the undergraduate and graduate levels. A New York City resident, I was at Ramapo College of New Jersey as the World Trade Center was attacked and fell. Faculty, of course, had no time to prepare whether, how, and what to teach. Tuning into student frame of reference was not something I yet knew from experts might be advisable to do then. But when I told students they could leave if they wanted to, or stay and watch and talk things through together, I found that everyone stayed. They spoke of their need for facts, answers, and community, of wanting to do something to help, and of being with those they could trust - just as the literature reviewed above suggests they would. Then they spoke of their feelings, with a candor and depth many have said their generation lacks - but which the literature reviewed above suggests they would, especially if they are reached through vehicles they are comfortable with. The questions they asked, and the feelings they stated are summarized in Appendix B.

With some students experiencing personal loss, with others being called up unexpectedly for active duty, with more questions being raised than consistent answers being given in public arenas, with fear a constant among students, and with that translating into student difficulty concentrating on class work, I designed for each class a combination of the teaching methods itemized in the survey, applying my experience with active learning to the uncharted waters students were presenting. Students were put in small groups to identify key questions they wanted answered. They each selected an Arab or Middle Eastern country they knew nothing of to research and report on, and to find examples of key course terms they were learning. Students from or representing different countries they knew well, including the U.S., volunteered to be participants in a class "Talk Show" in which they could share their knowledge, experience, and perspectives with their peers in a respectful forum facilitated by the professor, knowing sharing facts and objectively would be norms. An exam and final project specifications were re-written to allow individual critical thinking continuing that learning At semester's end, students said these methods assisted the return of their attention to coursework, increased their interest in and quality of their learning, strengthened their relationships to other students, and gave them an enduring interest in following current events. They said they could now understand current events and its relevance to their lives - something the literature reviewed above identified as vital. Importantly, they said they had learned to ask their own questions, and how to find their own answers.

One year later, engaged in an ongoing war on terrorism and uncertainty in the Middle East, there has been time to research expert recommendations for teaching in times of trauma (see Bibliography). I now knew, as the one year anniversary of 9/11/02 approached, to ask students if they were on active duty or were close to someone who is, and if they had been at or were close to someone who had been at the World Trade Center on 9/11/01. From this, I learned that one quiet student had been among the Marines who liberated Kandahar, and had just returned to school from nine months service overseas. Another had arrived in the U.S. from Zambia for the first time just days before 9/11/01; she had had no family or friends here and was "terrified," but was unable to leave as planes were not flying. Another student had seen the Twin Towers fall from her window, and described "looking at the sky for a month expecting a bomb to fall." Another expressed pride in his school, because of the tolerance and volunteerism shown. 
From this, drawing upon the prior year's experience and literature now reviewed, faced with the 9/11/01 one year anniversary and attendant media coverage, an active learning assignment tailored to the learning objectives and students of each class was created for each of my classes. Managerial Communication students viewed 9/11/02 media coverage using analytic communication tools. Contemporary Arts Management students viewed that media coverage applying analytic criteria media managers use in making decisions. Perspectives of Business and Society students inventoried that media for linked examples of key terms they had learned, and prepared a Talk Show in which those who wanted to reflect upon 9/11/01 one year later could volunteer as panelists (see Appendix C for description of that assignment). Students in all classes were given the opportunity to write up their findings for extra credit. The majority of students did so. The Talk Show was so memorable that we scheduled a second one for the following class. The topic was relevant to the course and a natural sequel: students from, or with knowledge of, other countries shared their information and experiences regarding topics central to the course. We learned about countries ranging from Afghanistan to Bulgaria, from Columbia to Zambia, and from Switzerland to Japan. More students volunteered than we could accommodate. More Talk Shows will be scheduled, as topics warrant.

The literature reviewed above suggests that incorporating student sharing of experiences/opinions, facilitating peer discussion, connecting course terms to topics already of interest to students, integrating media and communication vehicles students are comfortable with, providing them a way to "do something" and enhancing being part of a community will be both desired by and effective with today's students. The examples given above suggest some ways that can be done. One freshman described the outcome this way in the extra credit memo she submitted on $9 / 13 / 02$. The ideas and conclusions originated with her - they were not made in a lecture. She is 18 :

"After reading many articles about September 11 this week a lot of information was learned. Last year, when the attacks occurred, I didn't want to hear about it that much because that was all anyone seemed to talk about and the whole incident made me upset. One year later, I am able to read these articles. After just being in school for about one week, I look at the incident in two ways. While reading the articles, I looked at it from the point of view of an American teenager but I was able to understand it from an economic view. For the first time, I was able to see how this one incident affected the lives of not just the victims but everyone else in the world. Never before did I really understand how many individual businesses were hurt because of the attack. I really noticed the ripple effect that was caused by the attacks. The things people took for granted are now given their true importance. The attacks of September 11 showed America who the real heroes are, the people who help their country and their fellow Americans. It is very clear now that our economy is like dominoes. If one little aspect doesn't live up to its potential or if it is hurt in some way, the rest of the country gets hurt in some way or another."

\section{Conclusions}

In the wake of $9 / 11 / 01$, many educators are seeking to adapt to teaching post-9/11 on a timeline imposed by current events more quickly than they are used to or most academic literature can serve. Most initiatives described in the general media are curricular, not pedagogical, in nature. Curricular adaptations tend to be driven by educators, and some post-9/11 adaptations have generated public controversy. Most require significant research, and may delve into a subject area outside of the faculty member's expertise.

Alternatively, pedagogy that involves active learning tends to be student-driven and is accepted educational practice. Additionally, pedagogy that involves active learning coincides both with recommended approaches for post-trauma/terrorist actions and the communication habits of our students.

Student responses to the survey conducted for this paper are consistent with recommendations the reviewed literature suggest, and support the use of active learning tools as both desirable and effective in college teaching even more so at a four-year college and in business school classes. This would seem to be all the more the case when frames of reference are taken into account. Economic conditions are infused throughout business school classes, most see economic indicators to be not promising today, and business school students appear to make a strong connection between the continuing war on terrorism and a weakened economy. They are also grappling with headlines of corporate accounting scandals, as many prepare themselves for corporate employment. As one business student said in the extra credit assignment he submitted reflecting on 9/11/01 one year later: 
"The most important thing to me one year later is that the economy pulls through. As greedy as it sounds, I do not want to graduate college into a chaotic economy trying to find a job. I do not want to fight my way through hordes of people looking for work just like myself because corporations haven't gotten themselves together."

The events of 9/11/01 and the war on terrorism appear to be very much on students' minds one year later. Appendix B details the questions they asked on 9/13/02, in the Talk Show described above. They include these:

- $\quad$ "Are we going to prevent this without destroying civil liberties or going to war?"

- "Are we really safe now? How can we really know for certain we can relax? Will we ever be safe? "

- "What can I as a person do to help change this terror in our country and world?"

- "Why can't we do something about it - we can help the rest of the world, why can't we help ourselves?"

- "Will there be peace again in the world?"

Active learning techniques such as those described above not only help students learn, they help us as we strive to teach them by revealing to us in their own words where our students are coming from.

\section{Appendix A: Student Survey - Effective College Teaching Methods After 9/11/01}

\section{RESULTS}

\section{$\underline{\text { Respondents }}$}

Some 120 college students at two public institutions responded to a survey at the start of the Fall 2002 semester. One, Ramapo College of New Jersey, is a four-year college located about 45 minutes northwest of New York City. The other, Nassau Community College, is a two-year college located about 45 minutes east of New York City.

- $\quad$ Both lower level and upper level courses, attended by both business and liberal arts students, were surveyed.

- $\quad$ Fifty-two percent of respondents were business majors; $48 \%$ were undecided or liberal arts majors.

- $\quad$ Three-quarters of respondents attend Ramapo College of New Jersey. Of these, $41 \%$ were surveyed in upper level elective business courses (Contemporary Arts Management, and Business Operations Process Modeling); 59\% were surveyed in a lower level required business course (Business and Society).

- $\quad$ One-quarter of respondents attend Nassau Community College. They were surveyed in two sections of a lower level psychology course.

- $\quad$ An equal number of male and female students responded.

- $\quad$ Thirty percent of respondents were on active duty or knew someone who was, when responding.

- $\quad$ Thirty percent of respondents were at the World Trade Center or knew someone who was on 9/11/01.

Respondents answered survey questions using the following scale of 1 low to 5 high:

$1=$ never/not at all, $2=\mathrm{a}$ little, $3=$ somewhat $/$ more than a little, $4=\mathrm{a}$ lot, $5=$ always $/$ highly.

\section{FINDINGS}

1. Extent to which the events of $9 / 11 / 01$ and the war on terrorism that has followed were discussed in respondents' classes at each of these times:

- $\quad$ Discussion was high, and highest, on and within the month after 9/11/01; it has been relatively low since.

Table 1

\begin{tabular}{|l|c|c|c|c|}
\hline Discussion Occurred & $\mathbf{\% ~ 1 - 2}$ & $\mathbf{\% ~ 3}$ & $\mathbf{\% ~ 4 - 5}$ & Mean \\
\hline $\mathbf{9 / 1 1 / 0 1 - 1 0 / 1 1 / 0 1}$ & 10.3 & 18.8 & 70.9 & 3.98 \\
\hline $\mathbf{5 / 0 2}$ & 52.1 & 34.2 & 13.7 & 2.48 \\
\hline $\mathbf{9 / 0 2}$ & 64.3 & 22.6 & 13.0 & 2.21 \\
\hline
\end{tabular}


2. Extent to which respondents preferred the events of $9 / 11 / 01$ and the war on terrorism to have been discussed in their classes at each of these times:

- $\quad$ Respondents highly wanted discussion on or within the first month after 9/11/01; their preference is lower, and at a moderate level, now.

Table 2

\begin{tabular}{|l|c|c|c|c|}
\hline Discussion Wanted & \% 1-2 & \% 3 & \% 4-5 & Mean \\
\hline $\mathbf{9 / 1 1 / 0 1 - 1 0 / 1 1 / 0 1}$ & 4.3 & 18.8 & 76.9 & 4.14 \\
\hline $\mathbf{5 / 0 2}$ & 35.9 & 34.2 & 29.9 & 2.96 \\
\hline $\mathbf{9 / 0 2}$ & 41.9 & 28.2 & 29.9 & 2.89 \\
\hline
\end{tabular}

3. Extent to which respondents were interested in current events at each of these times:

- $\quad$ The majority of respondents reported a high level of interest in current events beginning with and continuing since $9 / 11 / 01$; that interest was highest on or within the first month after 9/11/01.

Table 3

\begin{tabular}{|l|r|r|r|c|}
\hline Current Event Interest & \% 1-2 & \% 3 & \% 4-5 & Mean \\
\hline Before 9/11/01 & 47.5 & 29.7 & 22.9 & 2.75 \\
\hline $\mathbf{9 / 1 1 / 0 1 - 1 0 / 1 1 / 0 1}$ & 3.4 & 6.8 & 89.8 & 4.52 \\
\hline $\mathbf{5 / 0 2}$ & 16.9 & 27.1 & 55.9 & 3.53 \\
\hline $\mathbf{9 / 0 2}$ & 22.9 & 25.4 & 51.7 & 3.46 \\
\hline
\end{tabular}

4. Extent to which respondents were interested in terrorism at each of these times:

- The majority of respondents reported a high level of interest in terrorism beginning with and continuing since $9 / 11 / 01$; that interest was highest on or within the first month after $9 / 11 / 01$, and correlates with respondents' reported level of interest in current events (see Q3 above).

Table 4

\begin{tabular}{|l|r|r|r|c|}
\hline Terrorism Interest & $\mathbf{\% ~ 1 - 2}$ & $\mathbf{\%}$ & $\mathbf{\% ~ 4 - 5}$ & Mean \\
\hline Before 9/11/01 & $\mathbf{7 2 . 0}$ & 21.2 & 6.8 & 1.94 \\
\hline $\mathbf{9 / 1 1 / 0 1 - 1 0 / 1 1 / 0 1}$ & 4.2 & 5.9 & 89.8 & 4.52 \\
\hline $\mathbf{5 / 0 2}$ & 14.4 & 25.4 & 60.2 & 3.65 \\
\hline $\mathbf{9 / 0 2}$ & 18.6 & 29.7 & 51.7 & 3.53 \\
\hline
\end{tabular}

5. Extent to which various teaching methods were used in respondents' classes to discuss the events of 9/11/01 and the war on terrorism, and respondents' perception of each method's effectiveness:

- The most highly used teaching methods were the most "traditional" of the teaching methods surveyed; they are teacher-student, in-class centered. Of these, interactive methods were seen more effective than lecture.

- $\quad$ The five most highly used teaching methods were used more than a little, and ranked among the five methods rated both most highly effective by respondents.

- $\quad$ Only class discussion of the events as seen in media/film/Internet appears to have been under-used as a teaching method felt to be more than a little effective by respondents.

- $\quad$ Overall level of use of the methods surveyed averaged 2.57; overall reported effectiveness of methods surveyed was similar (2.52) 
Table 5

\begin{tabular}{|ll|ll|}
\hline METHOD USAGE (most to least, by mean) & & METHOD EFFECTIVENESS (most to least, by mean) \\
\hline Teacher answers student questions & 3.45 & Students share opinions/feelings with class & 3.62 \\
\hline Students share opinions/feelings with class & 3.44 & Teacher answers student questions & 3.55 \\
\hline Teacher leads class discussion & 3.38 & Teacher leads class discussion & 3.48 \\
\hline Teacher lectures to class & 3.16 & Students tell their experiences to class & 3.37 \\
\hline Students tell their experiences to class & 3.09 & Teacher lectures to class & 3.11 \\
\hline Class discusses media/film/Internet & 2.77 & Class discusses media/film/Internet & 3.11 \\
\hline Student groups discuss, with teacher support & 2.34 & Student groups discuss, with teacher support & 2.76 \\
\hline $\begin{array}{l}\text { Teacher recommends media/film/Internet to learn } \\
\text { more about the events outside of class }\end{array}$ & 2.25 & Teacher recommends media/film/Internet to learn \\
\hline Graded assignments incorporate the events & 1.83 & Student groups research/report to class & 2.39 \\
\hline Student groups research/report to class & 1.81 & Guest speakers talk with class & 2.20 \\
\hline Optional/extra credit assignment re: events & 1.66 & Graded assignments incorporate the events & 2.10 \\
\hline Guest speakers talk with class & 1.63 & Optional/extra credit assignments re: events & 1.96 \\
\hline
\end{tabular}

6. Extent to which various teaching methods were preferred by respondents to discuss the events of 9/11/01 and the war on terrorism at each of these times:

- $\quad$ All five most highly used methods (see Q5 above) were among those most preferred by respondents in September 2001, and all but teacher lecturing to class are among those most preferred in September 2002.

- $\quad$ Respondents appear to have preferred a higher level of usage of these teaching methods in September 2001 than occurred (overall preference averaged 3.28; overall usage on and after 9/11/01 averaged 2.57, see Q5 above). Respondents continue to prefer a higher level of usage than has occurred (September 2002 preferences averaged 2.71; overall usage on and after 9/11/01 averaged 2.57, see Q5 above).

- Respondents also show an interest in more use of some active/experiential learning methods including discussion of the events as seen in media/film/Internet, student groups discussing the events with teacher support, and guest speakers talking about the events with the class.

- Opportunity to have questions answered, share opinions/feelings/experiences, and engage in teacher-facilitated peer discussion were methods most preferred by respondents in both September 2001 and 2002.

- $\quad$ Converting these events into assignments appears to be lowest priority for respondents.

Table 6

\begin{tabular}{|ll|ll|}
\hline METHOD PREFER FOR 9/01 (most to least, by mean) & \multicolumn{4}{l|}{ METHOD PREFER FOR 9/02 (most to least, by mean) } \\
\hline Teacher answers student questions & 3.95 & Students share opinions/feelings with class & 3.57 \\
\hline Students share opinions/feelings with class & 3.88 & Teacher answers student questions & 3.46 \\
\hline Students tell their experiences to class & 3.86 & Students tell their experiences to class & 3.40 \\
\hline Teacher leads class discussion & 3.76 & Teacher leads class discussion & 3.33 \\
\hline Teacher lectures to class & 3.38 & Guest speakers talk with class & 3.20 \\
\hline Class discusses media/film/Internet & 3.37 & Class discusses media/film/Internet & 3.09 \\
\hline Student groups discuss, with teacher support & 3.36 & Teacher lectures to class & 2.94 \\
\hline Guest speakers talk with class & 3.17 & Student groups discuss, with teacher support & 2.86 \\
\hline $\begin{array}{l}\text { Teacher recommends media/film/Internet to learn } \\
\text { More about the events outside of class }\end{array}$ & 2.95 & \multicolumn{2}{|l|}{ Teacher recommends media/film/Internet to learn } \\
\hline Student groups research and report to class & 2.68 & Optional/extra credit assignments re: events & 2.67 \\
\hline Optional/extra credit assignment re: events & 2.59 & Student groups research and report to class & 2.49 \\
\hline Graded assignments incorporate the events & 2.41 & Graded assignments incorporate the events & 2.42 \\
\hline
\end{tabular}




\section{4-YEAR COLLEGE BUSINESS STUDENT/2-YEAR COLLEGE PSYCHOLOGY STUDENT RESPONSE}

7. Teaching method preferred:

- 4-year college respondents, surveyed in business classes, reported greater preference for methods surveyed overall (3.23) than 2-year college respondents, surveyed in psychology classes (2.85); they also reported greater preference for each individual method except for teacher lectures to class and graded assignments.

- 4-year college respondents, surveyed in business classes, reported a relatively high level of interest in 8 out of the 12 methods surveyed.

Table 7
\begin{tabular}{|l|l|ll|}
\hline $\begin{array}{l}\text { METHOD PREFERRED AT 4-YEAR COLLEGE/ } \\
\text { BUSINESS CLASSES (most to least, by mean) }\end{array}$ & $\begin{array}{l}\text { METHOD PREFERRED AT 2-YEAR COLLEGE/ } \\
\text { PSYCHOLOGY CLASSES (most to least, by mean) }\end{array}$ \\
\hline Students share opinions/feelings with class & 3.83 & Teacher answers student questions & 3.45 \\
\hline Teacher answers student questions & 3.78 & Students share opinions/feelings with class & 3.35 \\
\hline Students tell their experiences to class & 3.76 & Teacher lectures to class & 3.31 \\
\hline Teacher leads class discussion & 3.73 & Students tell their experiences to class & 3.15 \\
\hline Class discusses media/film/Internet & 3.39 & Guest speakers talk with class & 2.96 \\
\hline Guest speakers talk with class & 3.25 & Teacher leads class discussion & 2.85 \\
\hline Student groups discuss, with teacher support & 3.23 & Student groups discuss, with teacher support & 2.66 \\
\hline Teacher lectures to class & 3.12 & Class discusses media/film/Internet & 2.61 \\
\hline $\begin{array}{l}\text { Teacher recommends media/film/Internet to learn } \\
\text { more about the events outside of class }\end{array}$ & 2.89 & $\begin{array}{l}\text { Teacher recommends media/film/Internet to learn } \\
\text { more about the events outside of class }\end{array}$ & 2.52 \\
\hline Student groups research and report to class & 2.62 & Student groups research/report to class & 2.44 \\
\hline Optional /extra credit assignments re: events & 2.57 & Optional/extra credit assignments re: events & 2.44 \\
\hline Graded assignments incorporate the events & 2.27 & Graded assignments incorporate the events & 2.44 \\
\hline
\end{tabular}

8. Extent to which class discussion occurred/was wanted, and level of interest in current events/terrorism:

- 9/11/01 raised interest at both 4-year and 2-year colleges in current events/terrorism, and is relatively high.

- 4-year college respondents, surveyed in business classes, reported more class discussion now re: events, a consistently greater desire for that discussion, and a stronger interest in both current events and terrorism than 2-year college respondents, surveyed in psychology classes; they also reported wanting more discussion of the events at all times surveyed for than occurred.

- 2-year college respondents reported more discussion of events in AY 2001-2002 than 4-year respondents

Table 8

\begin{tabular}{|l|c|c|c|c|c|c|c|c|}
\hline & \multicolumn{3}{|c|}{ 4-Year College/Business Classes } & \multicolumn{3}{c|}{ 2-Year College/Psychology Classes } \\
\cline { 2 - 9 } & Pre-9/01 & $9 / 01$ & $5 / 02$ & $9 / 02$ & Pre-9/01 & $9 / 01$ & $5 / 02$ & $9 / 02$ \\
\hline Discussion occurred & (not asked) & 3.94 & 2.46 & 2.42 & (not asked) & 4.11 & 2.54 & 1.52 \\
\hline Discussion wanted & (not asked) & 4.18 & 3.01 & 3.04 & (not asked) & 4.00 & 2.79 & 2.39 \\
\hline Cur. event interest & 2.90 & 4.53 & 3.61 & 3.60 & 2.25 & 4.46 & 3.25 & 3.00 \\
\hline Terrorism interest & 2.01 & 4.52 & 3.74 & 3.69 & 1.71 & 4.50 & 3.36 & 3.04 \\
\hline
\end{tabular}




\section{RESPONDENT COMMENTS (VERBATIM)}

- I think it is important for professors to talk about the events of 9/11 - especially now that a year has passed. We are still fighting a war on terrorism, but because it is not discussed that often people may forget.

- $\quad$ Discussion led by students is highly effective.

- $\quad$ Group sessions if students just want to vent their feelings. On grounds counseling.

- I believe the events of 9/11 had such a grip on people that the topic was intentionally not discussed. Perhaps the type of classes had something to do with this perception. Unfortunately, one of my closest friends worked in WTC1.

- $\quad$ I think I feel being as the anniversary's coming up that we should talk only if we think we're gonna get attacked again. Otherwise, I don't want to really hear about it.

- I I am a business student, only one of my teachers discussed 9/11 and that was only done once a year later. I really wanted to discuss the results in class but was never given the opportunity.

- I feel there should be a class on 9/11/01 and that we should have more therapy centers because I knew a lot of people in the area and one friend died there.

- It was discussed at every graduation I went to and during awards at school; it's time to move on. I'm interested when we are under terrorist warning. Teachers' effectiveness is limited, as they are baffled too.

- I I had a very delayed reaction to the events of $9 / 11$, and when it did hit me, no one was really talking about it. So I wasn't really sure if I was the only one still thinking about it. I think teachers should reach out a little more to students especially after an event like that.

- $\quad$ Lecturing doesn't do any good in the last. The most effective way to speak about terrorism etc. is to lead discussions with students being actively involved. Times have changed and so has society. If children aren't involved more in class, how are we teaching them to be intelligent leaders of tomorrow?

- What helped me get through the tragedy were relaxed class discussions that would go all period during the week after 9/11. Now media and lectures are more stimulating.

- I don't think there should be assignments regarding September $11^{\text {th }}$. Lectures and group discussions are fine. I think that research isn't al that great. I feel that due to the tragic events, it might be too heavy of a subject, for some.

- I I think the best effective way to teach about the events of $9 / 11$ is the media/Internet etc ... then followed by some guided discussions by the teacher.

- $\quad$ There should be more class talks on how $9 / 11$ is affecting the world today.

- I like to know why things happen. Why did they do it, how, and what things could have been done to prevent it.

- $\quad 9 / 11 / 01$ is something of interest to everyone. Therefore whatever is related in teaching to these horrible events will be more interesting. This could be a more effective teaching method. 
Appendix B: Student Feedback To Events Of September 11 - 14, 2001

\section{PERSPECTIVES OF BUSINESS AND SOCIETY (100 LEVEL, REQUIRED BUSINESS COURSE)}

Representative Student Questions

Could this have been prevented?

Did the U.S. shoot down the plane in Pennsylvania?

How did a terrorist attack successfully access the Pentagon?

How did our airports allow this to happen?

How do we know people in power will resolve it?

How do we react to people who are glad this has happened?

How do we stop terrorist acts?

How far will we go to find those responsible?

How long will healing and rebuilding take?

How will life change socially and economically if we go to war?

Is U.S. intelligence/military up to this task, when they didn't prevent it?

Is there going to be a traditional war with troops?

Is this the end of the world?

Should we fear that more terrorists are in the US?

What are the reasons behind the attacks?

What is U.S. doing about immigration?

What relationship do we have to Bin Laden?

What role did the U.S. play?

What steps will we take to prevent a recurrence?

What will happen to our economy?

What will the extent of retaliation be?

What will the U.S. response be?

What's next?

Where will relief money come from?

Why didn't the passengers rush the terrorists?

Why did they have to send a message when people were in the building?

Why did we not intervene quicker?

Why now?

Why us?

Who is behind this?

Will security affect our freedom?

\author{
Representative Student Feelings \\ Angry \\ Concerned \\ Confident \\ Confused \\ Damned \\ Devastated \\ Disheveled \\ Disturbed \\ Empathetic \\ Fearful \\ Frustrated \\ Grateful \\ Hate acts of violence \\ Heartbroken \\ Media too graphic \\ Not invisible \\ Not safe \\ Proud \\ Reflective \\ Relieved \\ Remorseful \\ Resentful \\ Sad \\ Scared \\ Shocked \\ Sorry for those who lost \\ Surprised \\ Terrible \\ Unified/reunited \\ Upset \\ Violated \\ Vulnerable \\ Want revenge
}

\section{REPRESENTATIVE FINAL PROJECT TOPICS INITIATED BY STUDENTS AT SEMESTER END}

Do children have too much access to deadly weapons?

Do sports promote violence in children?

Does a small business stand a chance in the big business world?

Does society incorrectly value human service careers as opposed to sports/entertainment careers?

Does the media shape social issues and attitudes?

How did business, government, and society handle the terrorist attacks and ripple effect associated with 9/11/01?

How is anthrax affecting Americans?

Is affirmative action fair, or is it reverse discrimination?

Is airline travel safer today than it was before 9/11/01? Are airlines using technology capable of preventing terrorim?

Is child labor humane throughout the world?

Is foreign direct investment good or bad for the United States?

Is the crisis in the Middle East the reason for the recent fluctuation of gasoline prices in the U.S.? 
Is the U.S. government responsible for Enron's ethical misconduct?

Is the World Trade Organization a positive influence on social and economic structure of underdeveloped countries? What environmental issues are shared globally, and what strategies can be used to address them?

Will government intervention caused by $9 / 11$ events help boost the economy?

\section{$\underline{\text { STUDENT FEEDBACK TO 9/11/01 AND WAR ON TERRORISM THAT FOLLOWED }}$ SEPTEMBER 2002}

Representative Student Questions: Perspectives Of Business And Society Class

- After we have tried to help so many countries, why do they continue to grow and learn to hate us so much?

- $\quad$ Are we going to prevent this without destroying civil liberties or going to war?

- $\quad$ Are we really safe now? How can we really know for certain we can relax? Will we ever be safe?

- $\quad$ Has government gone too far in response to 9/11?

- How could we have prevented this - how come the government didn't see this coming even though there was supposedly signs of an attack - how did the government and all those agencies we hear about all the time not know about something of this magnitude - where was the FBI? Why didn't our government do anything to prevent or prepare the country for what was about to happen? How do they find a way into the US - how does US security let that happen? How did our government let these terrorists stay in our country? It really makes you think hard about what the government is doing with all those tax dollars.

- $\quad$ How could someone be so cold and selfish - where do such pure evil plans come about, and how could those people actually go through with them?

- How could someone be so sick as to want to kill thousands of innocent people/civilians?

- How did they take the planes, what exactly happened in the planes, and what was going through the passengers' heads - what did they feel?

- $\quad$ How much did the US government actually know?

- I was watching TV the other day and a Muslim was on the air saying that she thought what happened was a terrible, BUT it had a good side in that she said more people were asking questions about Islam and trying to find out about it. I want to know that if I want people to learn more about Christianity would it be all right for me to fly a plane into the golden domed mosque in Jerusalem?

- Is our nation ever going to be the same?

- Is war the answer to the events of $9 / 11$ - what is the best response to the events that took place?

- What can I as a person do to help change this terror in our country and world?

- What compelled these people to attack our country - we will never negotiate with the terrorists, so what could they possible have tried to prove by this cowardly move? What result did the terrorists think that doing something so atrocious would have?

- What goes through a man's mind when he plans something so devastating - what were these people thinking when they did this to our country? What were they thinking as they planned and carried out the attack? How can people feel so much hate towards anyone?

- Why did all those innocent people have to lose their lives? Why did they have to pick an area with all innocent people who had nothing to do with government or political disagreements? What did America do to deserve this attack on its citizens? Why was it necessary to spill innocent blood?

- How can the terrorists use religion as the rationale? I'd like them to tell me exactly how their God could be the kind of God that would tell them to hate another nation that they know nothing about, and to kill so many innocent people for nothing, and no gain.

- What is it about the US that some people hate so much that they are willing to go to such trouble planning, funding, training the hijackers, and keeping it a secret through the years they were planning it? I think once this question is addressed the fight against terrorism can really begin to be fought.

- What does the US plan to put in the spot of the WTC?

- What is being done to help the families of the victims?

- What would the world be today if we stopped the terrorists before $9 / 11$ ?

- When is terrorism going to happen again - what will happen next?

- Where is Osama Bin Laden? 
- Why can't we do something about it - we can help the rest of the world, why can't we help ourselves?

- Why? Why us? Why did this have to happen to us?

- Why do we still make such a fuss about it? I know it sounds cruel stating such, but the more I hear about it the more angry I become. It is not that I do not care about it, I just want to get on with my life happily.

- Why would God, if such exists, allow such a disgusting, horrible, poor act of humanity to occur and affect, so negatively, the lives of so many innocent people?

- Will I, my children, and theirs ever be able to live in a world where we are safe from terrorist attack?

- Will there be peace again in the world?

\section{APPENDIX C: BUSINESS AND SOCIETY CLASS ASSIGNMENT $\quad$ SEPTEMBER 2002}

\section{TALK SHOW \#1: "9/11/01 - ONE YEAR LATER"}

As described in your syllabus, Talk Shows are a special feature of this course. Understanding of relevant contemporary issues is enriched through the sharing of personal experience between peers in an attentive, respectful forum. Four-five students may volunteer to serve as a panelist for each class talk show, and will receive extra credit for that contribution to class learning. All students will prepare, to facilitate the dialog that makes these sessions so memorable. Our first talk show is scheduled for Friday, 9/13/02. and is entitled "9/11/01 One Year Later." To prepare, you will read/watch at least three media sources (watch at least fifteen minutes of each source) written or broadcast between $9 / 4 / 02$ and $9 / 11 / 02$, and come to class with notes covering the following:

1. Give at least one example for each of the seven key terms learned in our first class: economic problem, business, government, society, stakeholder, social responsibility, ripple effect.

2. Complete each of these statements, being thoughtful and honest: *

1. The three most important things about $9 / 11 / 01$ are ...

2. The three most important things about $9 / 11 / 01$ to me are ...

3. When I think of $9 / 11 / 01$ I think of ...

4. One year after $9 / 11 / 01 \ldots$

5. The most important question I would like answered after $9 / 11 / 01$ is ...

\section{EXTRA CREDIT OPTIONS - OPTIONAL}

1. Talk Show Panelist - four-five student volunteers will receive extra credit for discussing their answers to the five statements (above *) with the class (five minutes per student). Talk Shows traditionally generate high students interest, involvement, and response. Every opportunity will be made to allow each student to serve as a panelist at least once during the semester. Panelists for Talk Show \#1 will be selected on 9/10/02.

2. Memo Report - you may submit a two to three page memo report on 9/13/02 using the following format:

$\underline{\text { Introduction }}$

Examples of key terms

1. Economic problem:

2. Business:

3. Government:

4. Society:

5. Stakeholder:

6. Social responsibility:

7. Ripple effect: 
$\underline{\text { Analysis }}$

1. The three most important things about $9 / 11 / 01$ are ...

2. The three most important things about $9 / 11 / 01$ to me are ...

3. When I think of $9 / 11 / 01$ I think of ...

4. One year after $9 / 11 / 01 \ldots$

5. The most important question I would like answered after $9 / 11 / 01$ is ...

Media Sources Consulted

1. Title, author/host/station/newspaper, date published/aired

2. Title, author/host/station/newspaper, date published/aired

3. Title, author/host/station/newspaper, date published/aired

Conclusion

\section{Bibliography}

Curriculum-Teaching-College

- $\quad$-----, "Correctness Crack-Up," Insight on the News, March 18, 2002

- $\quad$-----, "Idealism, Skepticism, Patriotism, More CNN," Washington Post, Nov. 4, 2001

- $\quad$-----,"The Question That We Should Be Asking," Newsweek, Dec. 17, 2001

- $\quad$ Argetsinger, "Schools Translate Terror Into Curriculum Changes," Washington Post, Feb. 8, 2002.

- Babwin, "Sept. 11 Terrorist Attacks Find Their Way Into College Classes," Washington Post, Nov. 25, 2001

- $\quad$ Birge, “Terrorism Coverage Takes Toll on Teaching," Quill, Nov. 2001

- Bombardieri, "A Change of Course: Vietnam Seminar Becomes Study in War on Terorism," Boston Globe, Nov. 4, 2001

- $\quad$ Cooperman, "A Timely Subject - and a Sore One: UNC Draws Fire,” Washington Post, Aug. 7, 2002

- $\quad$ Goodman, "What Do We Tell the Kids?" Washington Post, Oct. 6, 2001

- Healy, "Attacks Lead to New Academic Field at Colleges Across the Country," Boston Globe, Nov. 3, 2001

- $\quad$ Henry, “Teachers Try to Calm Fears of Their Students," USA Today.com, Sep. 12, 2001

- $\quad$ Labbe, "New Teachers Grapple With 9/11," Washington Post, Dec. 24, 2001

- $\quad$ Lakshmanan, "In Some Schools, Jihad, Anger at US Are Lessons," Boston Globe, Oct. 4, 2001

- $\quad$ Leo, "Professors Who See No Evil," U.S. News \& World Report, July 22, 2002

- $\quad$ Lord, "Real World 101," U.S. News \& World Report, Nov. 5, 2001

- $\quad$ Marklein, "Everyone's Seeking Answers Right Now," USAToday.com (online), Oct. 8, 2001

- $\quad$ Medina, "Schools Plan Curriculums That Focus on Sept. 11," New York Times, July 28, 2002

- $\quad$ Meltz, "For Many, 9/11 Fears Are Still Simmering," Boston Globe, March 7, 2002

- $\quad$ Nickerson, "Scholars Debate Meaning of 'Jihad," Boston Globe, Oct. 7, 2001

- $\quad$ Parachin, "How to Talk With Kids About Tough Issues," Vibrant Life, Sep.-Oct. 2000

- Peabody, "The Valley: Response to Terror: Students, Panel Discuss the War in Afghanistan," Los Angeles Times, Nov. 7, 2001

- $\quad$ Prentice, “An Ethics Lesson for Business Schools,” New York Times, Aug. 20, 2002

- $\quad$ Purnick, "In Schools, a Hidden Toll of Sept. 11," New York Times, May 13, 2002

- $\quad$ Reich, "Los Angeles: Educators Urged to Discuss Terrorism, Hate Crimes With Students," Los Angeles Times, Nov. 29, 2001

- $\quad$ Risinger, "Teaching About Terrorism, Islam, and Tolerance With the Internet," Social Education, Nov.Dec. 2001

- $\quad$ Seppenfield, "Paths to Patriotism: Since 9/11, Many Young Americans Have Wrestled With an Odd New Feeling," Christian Science Monitor, July 3, 2002

- $\quad$ Singleton, "Following a Tragic Event" Social Education, Nov.-Dec. 2001 
- $\quad$ Stepp, "The Lessons of History: After the Sept. 11 Attacks, Classroom Discussions Are Suddenly More Than Academic," Washington Post, Oct. 1, 2001

- $\quad$ Tawa, "Students Seek Solace in Classes on Sept. 11," Los Angeles Times, Feb. 7, 2002

- $\quad$ Van Biema, “A Kinder, Gentler Koran,” Time, Aug. 19, 2002

- Vlahos, "Some Post-9/11 College Courses Take a Twisted Path," Fox News Channel (online), Feb. 11, 2002

- Warner, "Life at the Woodrow Wilson School," New York Times, Dec. 23, 2001

- Z Zernike, "Lesson Plans for Sept. 11 Offer a Study in Discord,” New York Times, Aug. 31, 2002

Psychological Impacts - Violence

- $\quad$-----, "Children and Fear of War and Terrorism," National Association of School Psychologists (online), retrieved Sep. 1, 2002

- $\quad$----, “A National Tragedy: Helping Children Cope," National Association of School Psychologists (online), retrieved Sep. 1, 2002

- $\quad$-----, "New National Study Shows Degree of Exposure to 9/11 - Rather Than Degree of Loss - Predicts Level of Distress," American Psychological Association Online, retrieved Aug. 23, 2002

- $\quad$-----, "Study on Violent Kids has Surprising Results," CNN.com (online), Aug. 22, 2002

- $\quad$ Clay, "Research on 9/11: What Psychologists Have Learned So Far," Monitor on Psychology/Psychology in Education, Sep. 2002

- $\quad$ Daw, "What Have We Learned Since 9/11?" Monitor on Psychology/Psychology in Education, Sep. 2002

- $\quad$ Goode/Eakin, "Mental health: The Profession Tests its Limits," New York Times, Sep. 11, 2002

- Hamblen, Jessica, "How the Community May Be Affected by Media Coverage of the Terrorist Attack," National Center for Post Traumatic Stress Disorder (online), retrieved Aug. 23, 2002

- Hamblen, “Terrorist Attacks and Children," National Center for Post Traumatic Stress Disorder (online), retrieved Aug. 23, 2002

- Serlin, "Psychologists Working with Trauma: A Humanistic Approach," Monitor on Psychology/Psychology in Education, Sep. 2002

- $\quad$ Stevens, “The Psychological Impact of Terrorism," Link-up, Jan.-Feb. 2002

- $\quad$ Williams, "Coping with Fear," The Counseling Zone (online), retrieved Aug. 23, 2002

Media Habits - Gen X/Y

- $\quad$-----, “ News Audience Fragmented, Online New Use Up Sharply, Local News Interest Strong," Pew Research Center (online), 1998

- $\quad$-----, “ Public's News Habits Little Changed by September 11; Americans Lack Background to Follow International News," Pew Research Center (online), June 9, 2002

- $\quad$ Arnett, “Adolescents' Uses of Media for Self-Socialization," Journal of Youth and Adolescence, Oct. 1995

- $\quad$ Flowers, "This, Too, Shall Pass: Teenagers and the World Wide Web," School Library Journal, Nov. 1, 1998

- $\quad$ Frerking, “A Truer Picture of Teens’ Lives,” American Demographics, Nov. 2000

- $\quad$ Heath, "Tuning In to Talk," American Demographics, Feb. 1998

- $\quad$ Kingwell, "The Intellectual Possibilities of Television," Chronicle of Higher Education, Dec. 12, 1997

- $\quad$ Kohut, "Young People Are Reading - Everything But Newspapers," Columbia Journalism Review (online), July-Aug. 2002

- $\quad$ Marshall, "Tough Chat," The American Prospect, Sep.-Oct. 1998

- $\quad$ Nudd, "To Napster or Not to Napster?" Adweek, Aug. 14, 2000

- $\quad$ Parker, "A Uses and Gratification Perspective on the Internet as a New Information Source," American Business Review, June 2000

- $\quad$ Paul, "Getting Inside Gen Y," American Demographics, Sep. 2001

- $\quad$ Pursell, "Talk Shows Appeal to the Young and Out of School," Electronic Media, July 8, 2002

- $\quad$ Tobenkin, "Why We Like to Watch Talk TV," Broadcasting \& Cable, Sep. 28, 199 
Public Opinion

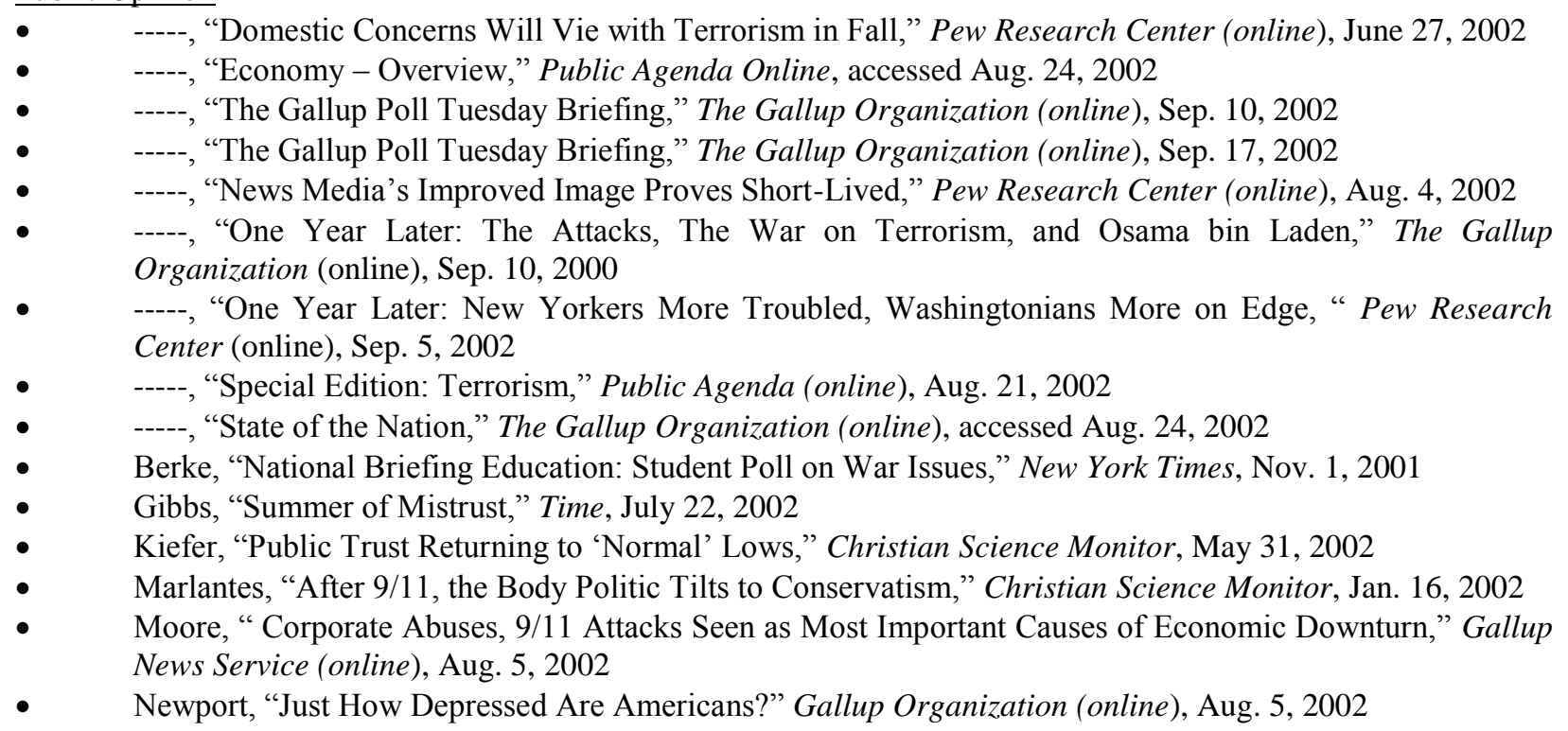

\section{Impact on U.S.}

- $\quad$-----, "Impact on the News," The NewsHour-PBS, Sep. 3, 2002

- $\quad$ Calandara, "History of Bull Markets Rile With Folly," CBS Marketwatch.com, July 30, 2002

- $\quad$ Garten, "Homeland Security Could Really Shake Up Business," Business Week, Sep. 2, 2002

- Hall, "Charities, Still Reeling, Try Some New Tacks," Christian Science Monitor, Aug. 5, 2002.

- Joyner, "New Corporate Reality a Sense of 'Cleaning up," Atlanta Journal-Constitution, July 21, 2002

- $\quad$ Plummer, "How We'll Remember Sept. 11," Atlanta Journal-Constitution, Aug. 4, 2002

- $\quad$ Seiler, "See-Change in Entertainment?" USAToday.com, Dec. 28, 2001

- Winter, "Fits and Starts as Companies Strain to Restore a Sense of Normalcy," New York Times, Sep. 18, 2001

\section{$\underline{\text { Impact on Careers }}$}

- $\quad$ Cannon, "Left a Good Job for Meaning," U.S. News \& World Report, Feb. 18, 2002

- $\quad$ Murdock, "More Helping Hands," Newsweek, June 10, 2002

- $\quad$ Rumbelow, "Work for Government? College Students Say No," Washington Post, July 17, 2002

- $\quad$ Terry, "Careers Reconsidered," Christian Science Monitor, Feb. 4, 2002

$\underline{\text { Impact on Arabs-Muslims }}$

- Rushdie, "Gods and Monsters: The War on Terror Will Only Be Won When Muslims Believe That Terrorism Is More Damaging Than America," Washington Post, June 28, 2002

- $\quad$ Samuels, “Attacks Drive Home Need for Tolerance," Washington Post, June 27, 2002

- $\quad$ Slackman, "Response to Terror: Saudis Feel Unfairly Tarred With a Terrorist Brush," Los Angeles Times, Jan. 17, 2002

\section{Acknowledgement}

Special thanks to Wendy J. Eisner, Ph.D, Associate Professor of Psychology, Nassau Community College, for assisting in data collection from her classes for use in the survey conducted for this paper. 
Notes 